\title{
Dual naming as a mechanism to recognize multiple identities; Casablanca or Ad-Dār al-Bayḍā
}

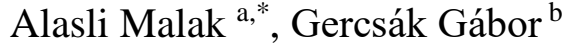 \\ ${ }^{a}$ Institute of Cartography and Geoinformatics, ELTE Eötvös Loránd University, Budapest, alaslima@ map.elte.hu \\ $\boldsymbol{b}$ Institute of Cartography and Geoinformatics, ELTE Eötvös Loránd University, Budapest, gercsak@map.elte.hu
}

\begin{abstract}
:
The primary aim of place names is to provide clear direction and reference in order to distinguish geographical entities. The Moroccan linguistic situation allows for a bilingual presentation of place names, with an Arabized version and a French counterpart that differs phonetically. On the other hand, Casablanca has dual naming, a colonial name, and an Arabic variant, which is not simply a translation that happened as a result of Arabization policies introduced after the country's independence. This study relies mainly on questionnaires, in addition to interviews, in an attempt to address the following aspects: The attitude towards the standardization of only one variant, variants and the city's cultural heritage and significance, standardization of only one variant and the accurate representation of the place, dual naming as a reminder of the multiple place histories vs. dual naming as a mere case of the language difference, and Moroccans and the etymology of the variants. The findings indicate that Casablanca shifts from a mere marker of the colonial period to an active maker of the city's heritage. Its meaning is disconnected from its historical anchorage and converted into an instrument of identity and means of historical memory. Moreover, the choice of one variant is perceived as a loss of toponymic identity, which will serve as a hindrance against the population and their relation to their past.
\end{abstract}

Keywords: dual-naming, identity, toponymy

\section{Introduction}

"Place-names are an important part of our geographical and cultural environment. They identify geographical entities of different kinds and represent irreplaceable cultural values of vital significance to people's sense of well-being and feeling at home." (Helleland, 2002).

The city is a convenient implementation framework for linguistic and toponymic analysis. It has linguistic (language), spatial (space), and historical (peoples' collective memory) associations. It is a complex and diverse place where language and spatial practices coexist. "Toponyms (place names) represent language units denoting elements of topographic environment" (Urazmetova \& Shamsutdinova, 2017).

The toponym plays an imperative role as it is the most apparent and readily accessible locator on the map. Naming a place allots differentiating one location from another by using specific names that appropriate it. In order to obtain efficient geographic information, the toponymy should be specific, accurate, identifiable, and recognizable in the field by both the inhabitants and the visitors. "Place names are closely linked to our sense of self, that is our identity. They are not mere signifiers of places but offer insight into the underlying perspective of communities."(Alasli, 2019).

\subsection{Theoretical background}

Toponyms are, by their very description, names for places. Place names reflect the place's spirit and reveal the language spoken in the area at the time of its denomination, which is seen in the persistence of several distinctive dialects in the place names. Another prevalent aspect of place names is that they register certain socioeconomic or sociocultural phenomena such as reclamation of land, land ownership, religion, historical events (Ekwall, 1960). Tuan (1991) has noted that 'normally only a socio-political revolution would bring sabout a change of name ... the new name itself has the power to wipe out the past and call forth the new'. Toponyms are a form of repositories of political, social, and cultural views of society. Moreover, they express language units denoting elements of the topographic environment. They are the linguistic signs of a natural language which constitute a system called a toponymic system. Toponyms make up a significant part of the lexical fund of the language. According to some researchers, the "toponymic layer constitutes $2-3 \%$ of common vocabulary" (Toporov, 1962).

\subsection{The linguistic situation in Morocco}

In North Africa, there are manifold toponymic layers correlated to the languages of the populations that succeeded in this region (ancient and modern Berber, Phoenician, Punic, Latin, Arabic, French, Spanish). Morocco assuredly possesses a rich toponymic heritage due to the heterogeneity of referents and references engaged in designating its places and territories. As a result, four languages coincide in the Moroccan public space, resulting in an incredibly intricate diglossia situation. "As all other names, toponyms belong to languages" (Tichelaar, 2002).

Morocco's primary language that ensures intercomprehension throughout the country is dialectal 
Arabic (Darija), which is spoken and understood by all, with the exception of a few enclaved Berber-speaking regions whose populations remain unilingual. In addition to two official languages; Standard/Classic Arabic (or Fusha), and Tamazight, the indigenous and oldest language in Morocco - commonly known as Berber. Besides, French, the former colonial language, and to a far lesser extent Spanish, which is another former colonial language now restricted to some Northern and Southern parts of Morocco. All these coexist with frequent code switching.

\subsection{Language and the appropriation of territories}

"Language is the principal characteristic of an ethnic group and the most important guarantee for the ongoing inheritance of its traditions" (Balázs, 1997). Moreover, "situation in the toponymy of Arab and African countries is strongly marked by their colonial heritage" (Zagórski, 2008). The European denomination of places and territories had become commonplace as soon as the Protectorate was established, owing to the Frenchization or partial Hispanization of place denomination. In the Moroccan context, language serves as a vector for territorial appropriation in the practice of territorial recompositions. Thus, since the 1970s, a postcolonial policy of Arabization strived to replace French. In the aftermath of the country's independence, toponymy's reArabization gradually restored its lost place to the Arabic language in the designation of places and spaces. The change in toponymy ached to express the dynasty's anchoring in the Arab-Muslim sphere by displaying its references to Arabity and Moroccanness at the time of political disputes. Cities like Ksar Es Souk, Louis Gentil, or Fedala have been renamed with reference to a Cherifian toponymy (Sultan Moulay Rachid, Moulay Youssef, Mohammed V) to become Errachidia, Youssoufia, and Mohammedia respectively.

The Arabization of place names does not always imply that the name is of Arabic origin; existing names are Arabized according to Arabic linguistic rules. For instance, Martil, a city in the north, derives its name from Spanish Río Martín, a colonial name at the time when the north and south of Morocco were two Spanish protectorates. The change of colonial names was usually motivated by the intent to erase any prior colonial history suggesting that that period either did not exist, was unimportant, or unwelcomed.

\subsection{The bilingual transcription of place names}

The Moroccan linguistic situation allows for a bilingual presentation of place names, an Arabized form, and its French equivalent where the specific linguistic context influences the toponym variant's choice. The main difference between these two presentations is a phonetic alteration to adjust it to the target language; Rabat vs. الرباط, Romanized: ar-ribāt. Thus, this dual presentation does not infer a problem in the communication. However, Casablanca holds two naming; a colonial name and the Arabic counterpart, which is not only a translation that occurred due to the Arabization policies implemented after the country's independence. Casablanca is the biggest city in Morocco and the only city name to hold dual naming.

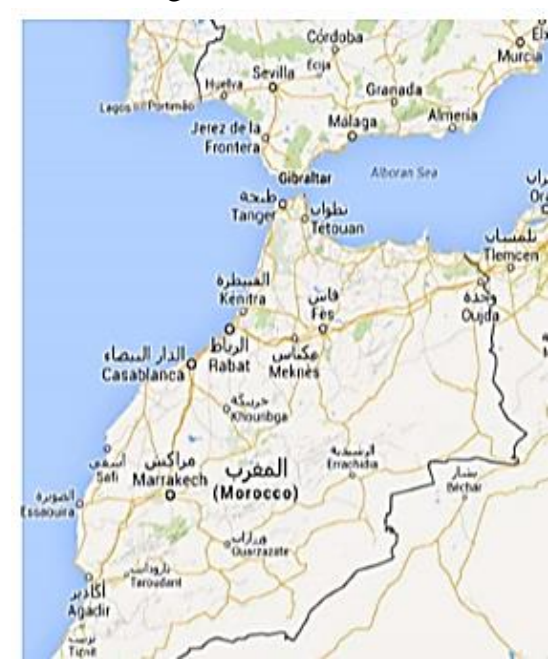

Figure 1. Map showing the bilingual transcription of the place names

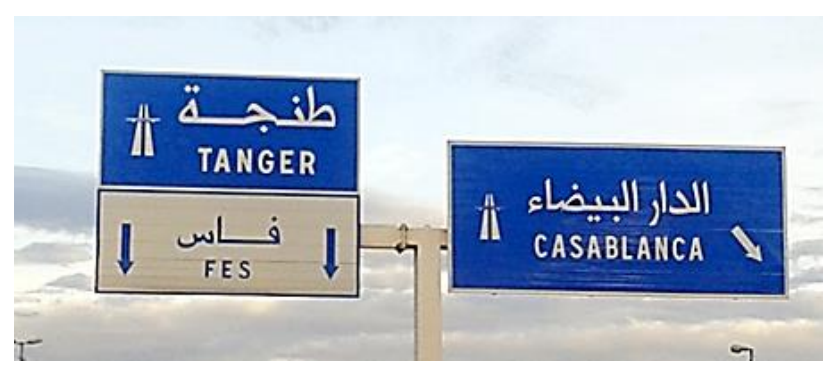

Figure 2. The bilingual representation of the place name

\section{Methodology}

\subsection{Area of study}

Casablanca (Ad-Dār al-Bayḍā) was previously called Anfa, meaning 'hill' in Amazigh. In addition, 'Tadart' is another Amazigh name that means a house, home, or dwelling, and it is most likely the city's first name in its early beginnings. After the Portuguese took control of the city in the 15 th century AD, they rebuilt it, changing the name to Casa Branca, which derives from the Portuguese word combination meaning white house. The present name, which is the Spanish version, came when the Portuguese kingdom was integrated in a personal union with the Spanish kingdom. During the French protectorate in Morocco, the name remained Casablanca. According to some archives, it was named Ad-Dār alBayḍa in 1755 when an earthquake destroyed most of the city and was rebuilt by sultan Mohammed Ben Abdellah who changed the name. Furthermore, it is locally known as 'caza' or 'darbida' (a shortened version).

\subsection{Data collection}

This investigation uses mainly questionnaires as they have "been used in studying criteria for name-giving" (Ainiala, 2016). The questionnaire was written in both Standard Arabic and French and administered to exclusively Moroccans. The participants were chosen 
randomly because of the need to gather dispatched data independent of any social criterion. Thus, creating a somehow heterogeneous group in terms of age, education, and social background. The questionnaire consisted of 13 questions, including personal information (social identity: gender, age). The questionnaire was then circulated to various participants to gather information on the relevant data.

Gillham (2000) notes that it is essential to provide the potential participant with clear information about what the questionnaire is asking; thus, the questionnaire title's wording was fundamentally important. Moreover, To increase the participants' positive regard towards the question, it was crucial to follow Thibaut and Kelley (1959) and explain 'that they are part of a selected sample and that their response is needed if the study is to be successful.' From the 150 questionnaires sent, 104 have been answered, providing an answer rate of around $69 \%$. Of the 104 respondents, 60 were females and 44 males.

The study primarily strives to investigate the attitudes towards the dual naming, and the choice of a superior or more appropriate variant. Further to this, more people will be interviewed to tackle the different goals of this research. The interviews will involve asking the participants both open-ended and specific questions. The foremost interest is on aspects such as:

What would be the reaction towards the standardization of only one variant? Which variant best preserves the city's cultural heritage and identity? Will keeping the two variants facilitate the preservation of the cultural significance of the place name? And will choosing one variant hinder the accurate representation of the place?

Toponymic identity (name) can exist in a similar way to place identity. Is the dual toponym a symbol of multiple identities? Is the use of the two toponyms a reminder of the multiple place histories and cultural identities? Do these two variants hold two separate identities or is it just a matter of language difference? Are Moroccans aware of the etymology of the two forms, or do they see it merely as a case of translation? Is the choice of Casablanca biased in favour of mainstream usage?

Another crucial motivation behind this study is the necessity to produce a set of data that permits more solid identification of the place in question by circumventing uncertainties, and more respect to the heritage by adhering to the proper use of toponyms both in written as well as in oral practice. For instance, Hungarians encounter several foreign (background, language) geographic names in various contexts. Hence the investigation of the importance of the two variants.

\section{Results and discussion}

104 participants were required to identify which variant they believe best preserves the city's cultural heritage and identity. $76.9 \%$ declared that both variants do, and $6.7 \%$ stated that other variants, such as ANFA, will perform this task better. They were also asked to confirm if keeping both would facilitate the preservation of the cultural significance of the place name, and $77.9 \%$ agreed.
Right at the beginning of the twentieth century, Rabat was designated as the country's administrative capital, while Casablanca was appointed as its economic capital. This decision marked a significant milestone in Moroccan history in general and in the history of Casablanca in particular. Casablanca emerged as a migration hub, drawing many people from urban and rural areas after being elevated to Morocco's leading manufacturing, commercial, and port city. As a result, the city's population rose from less than a million in the first half of the twentieth century to more than three million today, making it the largest Moroccan city by far. A percentage of the respondents view the nature of the dual naming as a mirror of the complexity and the various layers of its nature. Their acceptance of the dual naming was not merely in favour of its history, but as a current mirroring image of the city's various layers. In other words, the connections made by the participants are linked to the place itself rather to than to the name where "the meaning of the toponym relates to the referent" (Raportul et al., 1972).

The written form of a place name approved by a State is deemed to be an official name, in this case, both Casablanca and Ad-Dār al-Bayḍā. The purpose of place names is primarily to provide unambiguous direction and reference in order to identify geographical entities. An approach would be that whichever of the two names of the same feature most likely to be used by the local community is to be standardized. However, both are widely used with some local variations. Therefore, the dual presentation does not present a problem in the communication with the Moroccans. In an attempt to discern if the dual naming would hinder the ease of localization if foreigners used one variant instead of the other, $97.1 \%$ stated that they could facilely recognize the place in question. Nevertheless, foreigners do not tend to associate both variants with the same place. Consistent use of accurate place names is an imperative factor of effective communication worldwide and supports socioeconomic development, conservation, and national infrastructure. Hence the use of dual naming may hinder this particular role. I have encountered multiple people who have not associated Casablanca with Ad-Dār alBayḍā. Several foreigners, including Arab speakers, who would presumably understand the meaning of Ad-Dār alBayḍa, do not attach it to Casablanca as being the same place. A colleague of mine was shocked to know that Casablanca is, in fact, in Morocco and was more surprised to hear that Casablanca is Ad-Dār al-Bayḍā.

The proposal of one variant's choice needs to be investigated to establish if it would have enough community support to replace the other name. On asking about preserving the two variants as official toponyms, only $4.8 \%$ showed their disapproval, $39.4 \%$ had neutral reactions, while $55.8 \%$ agreed. The reasons behind, either the approval or disapproval of keeping the dual naming, ranged from the assumption that the two names are significant components of the city's history that display both sides of the location where we cannot remove one 
without neglecting parts of the other, to the conception that keeping both can be hinged on notions of colonial exploration. In other words, both variants are acceptable in the sense that their meaning is appropriate for its intended use. The majority of the respondents did not consider the Latin variant of Casablanca as offensive to the community; it, in fact, represented more their historical identity. Thus, place names are viewed as "a part of our cultural heritage in the sense that most have a story that tells something about that place that provides a sense of history about the first settlers of that areas" (Ghani, 2016). Etymologically speaking, adopting only one variant will erase part of the place's historical identity, as these two variants go beyond just a mere case of a linguistic difference to holding two separate identities $(52.9 \%)$. Following this reasoning, choosing one variant will hinder the accurate description of the place.

In contrast, what motivated those who supported the Arabized variant is the need for "the cleansing of previous place names" (Giraut \& Houssay-Holzschuch, 2016). Removing "colonially-allocated toponyms" (Kostanski, 2004) eliminates the links to colonial history from the landscape, map, and community. They saw Casablanca as a constant reminder of colonial history. An identity created by colonists and perpetuated by their descendants.

Nonetheless, names are "given intentionally, to impart a certain meaning." (Radding \& Western, 2010). Hence, if the choice is the Arabic version, what is its authenticity as the original name is of Amazigh roots? The number of Berber speakers "may represent between 35 percent and 40 percent of the whole population" (Caubet, 2008). Thus, if we follow this strain of reasoning of not approving a colonial variant, the Berber community might provide the same argument against the choice of Ad-Dār al-Bayḍā, as it is itself a colonial (Arab colonization) in a way. Thus, applying the same colonial cartographic perspective, "Classical Arabic is nobody's mother tongue because, in every Arabic-speaking country, the spoken language has evolved with society" (Valentina, 2017).

The choice of the one variant was perceived as a loss and a sign of disrespect for their toponymic identity, which will interfere with a population and their connection with their history. Place names remind us of "who we are, and whence we came, and are a rich source of information about a region's history. [They] also form an integral part of a nation's cultural and linguistic heritage, [. . .] [and] in many regions, they reveal the chronology of exploration and settlement." (Tent \& Slatyer, 2009). It is important to pass down historical meaning through the names of places with which they identify. In this manner, it can be seen that it is the toponymic identity that connects a population with their history. The perceived need to identify with colonial history and names diverges according to the memories or knowledge that people associated with the names. The proposition is clear here that a toponym can be a symbol of multiple identities, and the use of two toponyms for one place can be a potent reminder of the multiple place histories and cultural identities which exist for a locale.

Various respondents saw that it was in the community's interest that the variant Casablanca also be retained, claiming that both variants "contribute to shaping the cultural landscape" (Jordan, 2012). They argue that although both 'bidawa' and 'cazawa' are used as nicknames of the inhabitants of Casablanca, the latter is the most common and used one, which reflects the connections and attachment to that identity. "Society must...bear the responsibility for taking care of the placename heritage" (Helleland, 2002). Moreover, since it is known as Casablanca worldwide, the typical approach is to accept that the community's identity is that which is partially represented by the colonial name.

"Place names are also important in creating and maintaining emotional attachments to places." (Kearney and Bradley, 2009). Community definitions of inclusion and exclusion partly form place identity. Similarly, it can be seen that toponymic identity is partly formed through personal and community identification. "There is a close relation between toponymy and social psychology of a nation because accurate knowledge of place names is very important" (Poenaru-Girigan, 2013). People are more likely to form an identity with toponyms that they perceive to be 'normal' than those which are considered 'foreign'. Another minor percentage viewed that the reservation of both variants is best for reasons such as the familiarity of the colonial variant Casablanca, the Arab identity serving variant of Ad-Dār al-Bayḍā, and a more straightforward reason that of the broadcasted classical movie Casablanca, which projects some of the city's global impact. Lastly, 76.9\% stated that they do not know the exact history behind the naming.

\section{Conclusion}

Toponyms are markers of the diversity of representations and practices. They can also reveal historical variations in people's relations to a given space and claims over this space. Toponyms designate locations that are important to the functioning of societies. Place names have been found to be centres of conflicting denotations in various historical and geographical contexts. The evaluation of the research data on participants' perceptions towards dual naming gives insight on whether a toponym can carry multiple identities and how the use of two toponyms for one place can serve as a reminder of the multiple place histories and cultural identities.

The idea of a single version must be explored to see if it has enough community support to substitute the other name. In the sense that their interpretation is suitable for their intended use, both variants are acceptable. The majority of respondents did not regard the Latin variant of Casablanca to be insulting to the culture but rather reflected their historical identity.

It is commonly assumed that the act of marking places tends to control and imbue space with distinct beliefsystems and values, leading to the belief that Casablanca 
will serve as a constant reminder of colonial history and landscape ownership. Nonetheless, the effort to correct or modify the place name elicited mixed reactions, which elevates the place name Casablanca from being a mere marker of the colonial period to being an active maker of the place's heritage. Its meaning is disconnected from its historical anchorage and converted into an instrument of identity and means of historical memory. It performed more than its solely colonial cartographic perspective.

When the transparency of a place-name meaning is lost, the ability to identify and recognize the events characterizing these territories fade; the place name no longer carries out an act of remembrance. The bilingual transcription of Moroccan city names is primarily a matter of a phonetic alteration, and the choice of the pronunciation of one form over the other can be interpreted in a manner of diglossia (Rabat vs. Rbat), presenting a 'high' and 'low' status similar to the diglossic situation of the language itself. The case of Casablanca goes beyond a difference in pronunciation, offering a unique case of research.

\section{References}

Ainiala, T. (2016). Names in society. Hough, C. (Ed.) The Oxford Handbook of Names and Naming (pp. 413-423). Oxford University Press. http://oxfordhandbooks.com/view/10.1093/oxfordh b/9780199656431.001.0001/oxfordhb9780199656431-e-51

Alasli, M. (2019). Toponyms' contribution to identity: The case study of Rabat (Morocco). Proceedings of the ICA, 2(July), 1-7. https://doi.org/10.5194/icaproc-2-3-2019

Balázs, G. (1997). The Story of Hungarian: A Guide to the Language. Corvina Books

Caubet, D. (2008). Morocco (Vol. 3, pp. 287-297).

Ekwall, E. (1960). The concise oxford dictionary of English Place-Names.

Ghani, R. A. (2016). Place Names : Preserving Cultural Heritage, Reflecting National Identity. 1-13.

Giraut, F., \& Houssay-Holzschuch, M. (2016). Place Naming as Dispositif: Toward a Theoretical Framework. Geopolitics, 21(1), 1-21. https://doi.org/10.1080/14650045.2015.1134493

Helleland, B. (2002). The social and cultural value of place names. Eighth United Nations Conference on the Standardization of Geographical Names, 46693(July), 2-6.

Jordan, P. (2012). Place Names As Ingredients of SpaceRelated Identity. Oslo Studies in Language, 4(2). Fhttps://doi.org/10.5617/osla.314

Kearney, A. and Bradley, J. (2009): 'Too strong to ever not be there': place names and emotional geographies. Social and Cultural Geography 10, 77-94.

Kostanski, L. (2004). Duel-Names: How toponyms ( placenames) can represent hegemonic histories and alternative. 273-293.

Poenaru-Girigan, O.-M. (2013). The relationship between toponymy and linguistics. Anadiss, 8(15), 154-166.

Radding, L. \& Western, J. (2010). What's in a name? Linguistics, georgraphy, and toponyms. 100(3), 394-412.

Raportul, T., Toponimie, D., \& Lingvistică, Ş. I. (1972). On the relationship between toponym and Linguistics. 95-102.

Tent, J., \& Slatyer, H. (2009). Naming places on the "Southland": European place-naming practices from 1606 to 1803. Australian Historical Studies, 40(1), 5-31. https://doi.org/10.1080/10314610802662995

Tichelaar, T. (2002). Toponymy and language (pp. 1-17).

Tuan, Y. F. (1991). Language and the Making of Place: A Narrative-Descriptive Approach. Annals of the Association of American Geographers, 81(4), 684696. 8306.1991.tb01715.x https://doi.org/10.1111/j.1467-

Toporov, V. N. 1962. Iz oblasti teoreticheskoj toponomastiki. Voprosy jazykoznanija, (6), pp. 313. ISSN: 0373-658X.

Urazmetova, A. V., \& Shamsutdinova, J. K. (2017). Principles of place names classifications. XLinguae, 10(4), 26-33. https://doi.org/10.18355/XL.2017.10.04.03

Valentina, F. (2017). À propos du darija.

Zagórski, B. R. (2008). Standardization of Arabic and African place names in Poland. July, 1-23. 